\title{
THE IMPERATIVE SENTENCE IN DOLOKSANGGUL TOBA BATAK LANGUAGE
}

\author{
Imelda Malawaty Simorangkir \\ Prodi Pendidikan Bahasa Inggris, FBS Universitas Indraprasta PGRI \\ 21C7,imelsimorangkir@gmail.com \\ Yosi M. Passandaran \\ Prodi Pendidikan Bahasa Inggris, FBS Universitas Indraprasta PGRI \\ Pos-el: yosimpass@gmail.com
}

\begin{abstract}
The purpose of the research "The Imperative Sentence in Doloksanggul Toba Batak Language" is to find out the kinds of the imperative sentence structure and the characteristics of the imperative sentence between Toba Batak language in general and Toba Batak Doloksanggul. The theory is about kinds of sentence, especially imperative sentence. The imperative sentence also be called as a command sentence. Besides as a command sentence, imperative sentence also used to say request, prohibition that can be formed in a sentence. These sentences can be found in every language such as in Indonesian, the language of the tribes as well as foreign languages. Every language has characteristics itself, such as in Doloksanggul Toba Batak language in North Sumatera, Indonesia. Batak language Doloksanggul has differences with the Batak language is generally. The characteristics of imperative sentences in Doloksanggul Toba Batak language has differences. The differences can be found in the structure, the using of particle, and the using of vocabularies. The descrptive analysis method was used in this research. The analysis is taken from the interview for collecting the information. The result is the differences of imperative sentence characteristics between Toba Batak language in general and Doloksanggul Batak Toba are (1) the difference in structure, (2) the using of particle 'ma' in Doloksanggul Batak Toba, and (3) the using of intonation; and the similarities of imperative sentence are (1) the basic structure of positive and negative sentence, (1) both of the language use the same particle 'do', and (3) both of the language uses the word 'tongka' as a negatif expression. The conclusion is the imperative sentence structure between Toba Batak in general and Doloksanggul Toba Batak language have any differences and similarities.
\end{abstract}

Keywords: types of imperative sentence, characteristics of imperative sentence, Doloksanggul Toba Batak language.

\begin{abstract}
ABSTRAK
Penelitian yang berjudul The Imperative Sentence in Doloksanggul Toba Batak Language bertujuan untuk mengetahui jenis, struktur, dan karakteristik kalimat imperatif antara bahasa Batak Toba secara umum dan Batak Toba Doloksanggul. Teori yang diterapkan dalam penelitian ini adalah teori jenis kalimat, terutama kalimat imperatif. Kalimat imperatif juga dapat disebut sebagai kalimat perintah. Selain sebagai kalimat perintah, kalimat imperatif juga digunakan untuk mengatakan permintaan, larangan yang dibentuk ke dalam sebuah kalimat. Kalimat-kalimat ini dapat ditemukan juga pada setiap bahasa seperti pada bahasa Indonesia, bahasa suku maupun bahasa-bahasa asing. Setiap bahasa memiliki karakteristiknya sendiri separti pada bahasa Batak Doloksanggul di daerah Sumatera Utara, Indonesia. Bahasa Batak Doloksanggul memiliki perbedaan pada bahasa Batak umumnya. Karakteristik pada bahasa Batak Doloksanggul mempunyai perbedaan. Perbedaan tersebut dapat ditemukan dalam
\end{abstract}


strukturnya, penggunaan partikel-partikelnya, dan penggunaan kosa kata-kosa katanya. Metode penelitian yang digunakan adalah metode deskriptif analisis. Analisis diambil dari hasil wawancara dalam pengumpulan data. Hasilnya adalah jenis karakteristik perbedaan kalimat imperatif antara bahasa Batak Toba secara umum dan Batak Toba Doloksanggul adalah (1) perbedaan struktur (2) penggunaan partikel 'ma', dan (3) intonasi. Sedangkan persamaannya adalah (1) struktur kalimat dasar kalimat imperatif positif dan negatif, (2) keduanya menggunakan partikel 'do', dan (3) keduanya menggunakan kata 'tongka' sebagai ekspresi pernyataan negatif. Kesimpulannya adalah jenis dan struktur kalimat imperatif antara bahasa Batak Toba secara umum dan Batak Toba Doloksanggul terdapat perbedaan dan persamaan.

\section{Kata Kunci: tipe-tipe kalimat imperatif, karakteristik kalimat imperatif, bahasa Batak Toba Doloksanggul}

\section{INTRODUCTION}

Language is used in contexts of communication, it is bound up with culture in multiple and complex ways. We can se the function of language as a means of communication in which vocal sounds are combined into meaningful units to convey thoughts, feelings; and human speech'.

We used sentence to say something to people. Sentence is a grammatical unit that is composed of one or more clauses (Loos, et. al., 2004). Another statement, sentences are tend to describe them as grammatically complete unit capable of standing on their own and semantically independent (Finch 2005: 109). This statement means the sentence is one of the tool of language as a menas of communication and because a sentence has a meaning itself.

Radford (2009: 253) said that based on the function, sentence can be devided into four kinds. They are declarative, interrogative, imperative, and exclamative. Based on each function of sentence has a difference grammatical structure in it. For example is imperative sentence. It is used to issue an order or command. It is similar to Karepouwan (2013), that stated, "imperative sentence is used to give command, warning, advise, instruction, and request". Imperative structure has frequently been regarded as derived from affirmative structures by deletion of a second person subject.

Ujaran imperatif adalah tindak tutur yang membuat seseorang untuk melakukan dan tidak melakukan sesuatu (Amelia, 2012). As a speech act, imperative is aimed to the politeness. The politeness in imperative can be indicate in (1) panjang pendek tuturan, (2) urutan tutur, (3) intonasi dan isyarat kinesik, dan (4) ungkapan penanda kesantunan (Rahardi, 1999).

It is often asserted that imperatives do not have subjects or, if they do, the options are very limited (Potsdam, 2003). So, it can be defined that a sentence is possible without subject in imperative. It is common in imperative.

The structure of every possible imperative sentence is seen as the result of an interrelated set of choices from five district binary system; the presence or absence of a 'subject' is shown to be irrelevant to all but one of these system. Some attempt will also be made to suggest some of the situation factors which affect the choice of any particular imperative structure to give the contextual meaning of each term in the various meaning.

Imperative sentences contain commands, request, prohibition, and addreesed by the speaker to the addresee in order to do something. Imperative sentences are generally terminated with an exlamation mark instead of period.

Description of Doloksanggul is given by Sibarani (1997: 1), "Indonesia has five groups of Batak tribe, namely The Batak Toba, The Batak Karo, The Batak Simalungun, The Batak Pakpak, and The Batak Mandailing."Batak Toba language is an ethnic language in Indonesia. Batak Toba language is spoken by Toba ethnic society, especially in Doloksanggul. They used 
this language in their daily conversation beside Indonesia language to communicate with other some age, particularly the younger generation become less in using this language.

Doloksanggul Toba Batak (DTB) is the sub-district in Humbang Hasundutan, North Sumatera. Doloksanggul is the district capital of Humbang Hasundutan. By Broad Land Area: $2,502,71 \mathrm{~km}^{2}$ comprised of 10 district, one village and 143 villages. Life has a population of 171,687 which consist of 85,274 people and 86,413 women. Doloksanggul friendly community, the organization very important in the lives of citizens Doloksanggul, The majorly clan in Doloksanggul is Lumban Gaol, Lumban Raja, Marbun, Nababan, Sianturi, Sihite, Sihotang, Sihombing, Situmorang.

Imperative sentence in Toba Batak (TB) is used to give command, request, permission, advise, invitation, prohibition, compulsion, and warning which quite same with English language. In Doloksanggul Toba Batak language has a little differences in imperative sentence than Batak language commonly. For example in Batak language, the sentence "ro ho tu jabu nami!" (come to my house), and in Doloksanggul Toba Batak language the sentence becomes "ro ma ho tu jabu nami!" (come to my house).In Doloksanggul Toba Batak language the particle " $m a$ " often appears in imperative sentence. The function of the particle " $m a$ " as a stressing tone.

From the above explanation, that is the reason to choose the topic about the structure of imperative sentences in Doloksanggul Toba Batak language. To find out Toba Batak language is a unique things which concerned with structure of imperative sentences in Doloksanggul Toba Batak language. To compare the both of Toba Batak languages (Toba Batak commonly and Doloksanggul Toba Batak). From this research the writer will find kinds and the characteristics of Doloksanggul Toba Batak language from imperative sentence itself.

\section{METHODOLOGY}

This writing used qualitative methode and descriptive analysis to describe the data. The data are taken from native speaker of Doloksanggul Toba Batak language as the informan by interviewing.

The steps to collect the data, are: (1) Choose the informans as source data by random sampling from population of the native speaker of Doloksanggul Toba Batak language in Medan Sunggal North Sumatera; (2) Ask the informans to make simple conversation in Toba Batak Language (TB) and Doloksanggul Toba Batak language (DTB); (3) The data was taken by conversation with native speaker and recording the data; and (4) Written the data in the transcript dialogues

After taken the data, the collecting data will be analyzed. It is the way to organize the data before they are analyzed. The ways of data analysis are: (1) Reduce the data by choose the data based on the objective of this research; (2) Make the code of each of kinds of data; (3) Find the characterictics of data; (4) Make classification the data; (5) Describe the classified data into kinds of imperative sentence; (6) Analyze the data from the transcript based on the theory of imperative sentence; and (7) Make conclusion from the analysis.

\section{DISCUSSION}

\section{Imperative Sentence}

Kalimat imperatif adalah kalimat yang mengandung makna perintah atau larangan; dalam ragam tulis ditandai oleh (.) atau (!). Dalam bahasa Indonesia ditandai oleh partikel seru '-lah' atau kata-kata seperti: 'hendaknya', 'jangan', dsb (Kridalaksana, 2008: 104). The 
imperative tense in English is used to give an order, a warning, an appeal, an advice, a suggestion, an instruction and in some cases a request to another person, to a group of people or to animals. It is very easy to form the imperative sentence: simply take the verbs' infinitive form (without the "to" infinitive indicator). Usually the verb will be placed at beginning of the sentence.

The discussion above similar to Isaraj (2010) said,

Within the group of imperative sentences there are distinguished the sentences that simply express a speaker's will and the sentences that express the active attitude of the speaker towards what he wishes to do or have and his efforts to make others perform or not an activity. The grammatical category of mood is the main means to express the modality of will in the form of a wish, order, request, advice etc.

Imperative sentences can be devided into two kinds, they are:

\section{a. Types of Imperative Sentence}

1) Positive Imperative Sentences

Generally, in imperative sentence, it is unnecessary to indicate the subject because the second person of the address is directly understood.

e.g. : Come here!

Positive imperative sentences in both transitive and intransitive verbs can be used. Transitive verbs have the direct object and the intransitive verbs are absence of direct object.

Transitive verbs: Help me please!

Intransitive verbs: Sit down please!

2) Negative Imperative Sentences

The statement about negative imperative sentence comes from Aikhenvald (2014), "negative imperative implies trying to make someone not do something, having the effect of forbidding, preventing, or excluding; preventative or restricyive of something". Lewis (Beauman, 1988: 369) also stated, “the negative imperative froms are represented by: don't (analytical) + infinitive constructions."

e.g. : Don't worry.

In this case the in dicative and imperative show a homonymy in the verb forms, except for the verb 'to be', which in negative does not take the auxiliary 'do', but the negative particle 'not'.

e.g. : Don't go there!

The negative imperative as prohibitions are often indicated by means of a brief announcement with "no + gerund".

e.g. : No smoking!

\section{The Functions of Imperative Sentence}

1) The Imperative Sentences as a Request

Actually imperative sentences as a request same with the command, but it is more polite. A request in an intention of the speaker, so that the listener does something.

e.g : Can I borrow your pen?

2) The Imperative Sentence as a Command

The command is given when there is a power different between speaker and listener, the speaker has an authority to command the listener to do something.

e.g. : Take out your dress! 
3) The Imperative Sentences as Prohibition

In prohibition, the speaker forbids the listener to do something. It is concerned with the negative imperative.

e.g.: Don't be late for school!

\section{How does Imperative Sentence in Doloksanggul Batak Language and Toba Batak Language Generally}

a. The types of Imperative Sentence

1) Positive Imperative Sentences

Positive Imperative Sentences included command, request, and prohibition whether formally and informally. Positive imperative sentences are directed at addressee (s) and the second person is not normally expressed because has already understood.

(1) DTB :Ro ma ho tu jabu nami!

TB : Ro ho tu jabu nami!

Iplease come to our house

(2) DTB :Buat piring i!

TB :Pinggan i buat!

Itake the plate!

(3) DTB :Taruhon ma sisir i!

TB :Taruhon ma suri i!

/give back the comb/

\section{Negative Imperative Sentences}

The negative imperative sentences is always signaled by the prohibition marker "unang", "tongka"," $i$ ".

(1) DTB :Unang dipamago ho tintin i!

TB :So tung dimagohon ho tintin i! /don't lose the ring/

(2) DTB : Tongka mandokkon goar ni natua-tua!

TB :Tongka do dohonon goar ni natua-tua!

Idon't say your mother namel

(3) DTB:Unang ho jonok tu asar ni ulok

TB :So tung jonok ma ho tu asar ni ulok i

Idon't go near to the snake nest/

\section{b. The Function of The Imperative Sentences}

1) The Imperative Sentences as a Command Imperative sentence is used without being followed by a pure smooth words and are usually used to tell the speaker that lower social status or age. This imperative called simple command because it does not use the word subtle. But the social and cultural conditions in a communication sometimes require a smoothing effect that the language of communication is pleasant to the speaker:

(1) DTB :Laho ma ho 

TB :Laho ma hamu
/go away/
(2) DTB :Buathon piring $i$
TB :Pinggan i jolo buat
/Take a plate!/
(3) DTB : Hundul ho
TB : Hundul hamu
/sit down, please/
(4) DTB : Taruhon ma suri $i$
TB : Taruhon ma sisir $\mathrm{i}$
/Take a comb/
(5) DTB :Buathon sonduk $i$
TB :Buat jolo sonduk i
/get the spoon!/

2) The Imperative Sentences as a Request

To form sentences in a language command Toba Batak, the particle "jo" used after particle. Discuss in the text command request Toba Batak if we ask someone to take something more polite to us. The function pinggirhon like the right hand is more dominant than the left hand so that if we get someone to do something with his left hand so that means no disturbing.

(1) DTB: Pinggirhon jo parbasuon i!

TB : Hambiranghon jolo cuci tangan i!

/Take the hand washing!/

(2) DTB: Lean jo panggu on tu ibana!

TB : Lehon hamu ma jolo panggu on tu ibana

/Please give this hoe to him/

(3) DTB: Sip jo!

TB : Sip jolo.

/Be quiet./

(4) DTB : Sori jo, di jabu ma hamu.

TB : Santabi di jabu jolo hamu ate /Please stay cool at this home/

3) The Imperative Sentences as a Prohibition

When the speaker wants to prohibit the addressee (s) to do something, the word marker are "tongka", "unang", "i".

(1) DTB: Tongka mandokhon goarni natua-tua

TB : Tongka do dohonon goarni natua-tua

/Don't say your mother name/

(2) DTB : Unang adong na meret sian on

TB : Unang adong na morot sian on.

/Don't move from here/

(3) DTB : Unang pamago tintin $i$

TB :So tung diagohon ho tintin $i$

/Don't lose the ring/

(4) DTB : Unang ho jonok tu asar ni uloki

TB : So tung jonok ma ho tu asar ni ulok $i$ 
/Don't go near to the snake nest/

\section{The Analysis of Imperative Sentence in Doloksanggul Toba Batak (DTB) Language and} Toba Batak (TB) Language Generally

From the data, the kinds of sentences found in the data can be analized based on the types of imperative sentence and the function of imperative sentence. The analysis can showed below.

a. The Types of Imperative Sentence in Doloksanggul Toba Batak (DTB) Language and Toba Batak (TB) language generally

1) Positive Imperative Sentence

(1) DTB: Ro ma ho tu jabu nami

TB : Ro ho tu jabu nami

In sentence above, the Doloksanggul Toba Batak language (DTB) sentence, the word ' $m a$ ' as a particle is followed by the word ' $h o$ ' as a subject. In Toba Batak language generally (TB), it doesn't find the word ' $m a$ ' as a particle. The placement of the word ' $r o$ ' as a verb is followed by subject ' $h o$ '. Besides as a particle, the word ' $m a$ ' also to give a stressto say the purpose of the sentence.

\section{(2) DTB : Buat piring $i$}

TB : pinggan i buat

In the sentence above, there are difference way to say 'plate'. In DTB language, 'plate' is 'piring' but in TB language generally 'plate' is 'pinggan' (polite word in Batak language generally). As the structure of imperative sentence between the both of languages, in DTB language the word 'buat' as a verb is placed in front of the sentence before the object 'piring' and article ' $i$ '. In the TB language generally, the 'buat' as a verb is placed in the end of sentence after the object 'pinggan' and the article 'i'.

(3) DTB :taruhon ma sisir $i$

TB : taruhon ma suri

In sentence above, there is the differences for using (Noun) between the both of languages. In DTB language, the noun 'comb' is written as 'sisir' but in TB language generally, 'comb' is written as 'suri'. For the structure of the sentence, there is no difference between the both of languages.

From all of the data in the positive imperative sentence, there are some differences such as in the structure and the function. The difference of the structure can be seen in using subject, verb, and noun. The difference in the function can be seen in using particle ' $m a$ '. It's only as a stress to say the purpose of the sentence.

2) Negative Imperative Sentence

(1) DTB: unang dipamago ho tintin i!

TB :so tung dimagohon ho tintin i!

In sentence above, there was the difference in the word 'don't'. 'Don't' in DTB language is 'unang' but in TBL is 'so tung'. The word 'lose' in DBL "dipamago' but in TB language generally 'dimagohon'. From the structure,the difference using of negative 
auxiliary verb 'don' $t$ ' in DTB language 'unang' and in TB language generally 'so tung'. The verb 'lose', in DTB language is 'dipamago' as verb but in TB language generally "dimagohon' as verb. In the structure of the both of languages, there are no differences.

(2) DTB: tongka mandokkon goarni natua tua!

TB: tongka do dohonon goar ni natua-tua!

In sentence number (2) above, the difference is the word 'say' in DTB language is 'mandokkon' but in TB language generally is 'dohonon'. In DTB doesn't use 'do' as a particle in the sentence but in TB language generally uses particle 'do'. Particle 'do' in TBL is placed after the word 'tongka' as negative auxiliary verb. The structure of sentences in the both of languages there is no difference.

(3) DTB :Unang ho jonok tu asar ni ulok i!

TB:So tung jonok ma ho tu asar ni ulok i/

In sentence number (3) above, the differences are the word 'don' $t$ ' in DTB 'unang' but in TB 'so tung'. In DBL, there is no use the word ' $m a$ ' as a particle, but in TB uses the word ' $m a$ ' as a particle. In DTB, subject (S) 'ho' (you) is placed after negative auxiliary verb and before the word 'jonok' as a verb. But in TB language generally, subject ' $h o$ ' is placed after the word ' $m a$ ' as a particle. The both of sentences (DTB and TB), the placement of object compliment is in the end of the sentence.

The structures of sentences between DTB and TB have differences. The difference is the placement of subject 'ho' in DTB. The word ' $h o$ ' as subject is placed after the word 'unang' as negative auxiliary verb and before 'jonok' as a verb. In TB, ' $h o$ ' as a subject is placed after 'so tung' as a negative auxiliary verb, 'jonok' as a verb, and ' $m a$ ' as particle.

From all the data, the both of language have differences and similarity. The differences are in DTB, negative auxiliary verb is 'unang' but in TB is 'so tung'. The verb lose, in DTB is 'pananggo' (active verb) but in TB is 'diangggohon' (passive verb). The verb 'say' in DTB is 'mandokkon' but in TB is 'dohonon'. In the structure of sentences between DTB and TB, the difference placement the word 'ho' as a subject. The other difference is the using of the word ' $d o$ ' as particle in TB only.

The similarity of the both of language (DTB and TB) is the both of the sentences in DTB and TB use the word 'tongka' to say don't. The placement of the word 'ni' as a particle before the word 'ulok' as a noun (in the object compliment).

\section{b. The Function of Imperative Sentence in Doloksanggul Toba Batak (DTB) Language and Toba Batak (TB) Language}

1) The Imperative Sentence as a Command

(1) DTB: Laho ma ho

\section{TB :Laho ma hamu}

In sentence above, the structure can be analyzed as follows in DTB "laho ma ho". The imperative sentences as command can be showed with word "laho' as a command, " $m a$ " is the particle, "ho" is the object. In TB, "laho ma hamu". The imperative sentences as command can be showed with word "laho' as a command, "ma" is the particle, "hamu" is the object.

The word ' $h o$ ' and 'hamu' is as a subject. In DTB always use ' $h o$ ' but in TB use 'hamu' to say you.

(2) DTB: Buathon piring $i$ 
TB : Pinggan i jolo buat

In sentence number (2), the structure can be analyzed as follows in DTB "Buathon piring $i "$. The imperative sentences as command can be showed with word "Buathon/buat" as a command, while "piring" is the object and " $\mathrm{i}$ " is article. But in TB, 'Pinggan i jolo buat'. The imperative sentences as command can be showed with word 'Pinggan' is the object, ' $i$ ' is adverb direction, 'jolo'is a particle, 'buat' as a command.

The differences between the both of languages in the sentences is the placement of 'buathon'. In DTB 'buathon' is in front of the sentence and is placed before word 'piring $i$ '. But in TB 'buat' is placed in the end of sentence after word 'pinggan $i$ '.

(3) DTB: Hundul ho

\section{TB : Hundul hamu}

In sentence number (3), the structure can be analyzed as follows in DTB "Hundul $h o$ ". The imperative sentences as a command can be showed with word "Hundul" as a command, while " $h o$ " is the object. In TB generally, "Hundul hamu". The imperative sentences as a command can be showed with word "Hundul" as a command, while "hamu" is the object. There is no differences between DTB and TB language generally in structure of sentence.

(4) DTB: Taruhon ma sisir $i$

TB : Taruhon ma suri $i$

In sentence number (4), the structure can be analyzed as follows in DTB language "taruhon ma sisir i". The imperative sentences as a command can be showed with word "taruhon" as a command, while "ma" is the particle, and "suri" is the object, " $i$ " is the adverb of direction. In the TB language generally "taruhon ma suri i".

The imperative sentences as a command can be showed with word "taruhon" as a command, while "ma" is the particle, and "suri" is the object, " $i$ " is the adverb of direction. There is no differences between DTB and TB language generally in structure of sentence.

(5) DTB: Buathon sonduk $i$

TB : Buat jolo sonduk $i$

In sentence number (5), the structure can be analyzed as follows in DTB language "Buathon sonduk $i$ ". The imperative sentences as a command can be showed with word "Buat" as a command, while "hon" is the object, "sonduk" is the object, and " $i$ " is the adverb of direction. But in TB language generally, 'buat' as a command, 'jolo' as a particle, 'sonduk' is the object, and ' $\mathrm{i}$ ' is the adverb of direction.

The differences between DTB language and TB language generally are for the word 'jolo'. In TB word 'jolo' is placed after word 'buat' as a command. But in TB dosen't use 'jolo' follows 'buathon' as a command.

From all the data in imperative sentences as a command have some differences. Some differences are for placement 'buathon' in DTB language and 'buat' in TB language generally. But sometimes the placement word 'buathon' and 'word 'buat' are in same position, they are placed in front of sentence. For word 'jolo' in TB is placed before 'buat' or 'jolo' follows 'buat' as a command. Some of sentences have a similar structure between DTB and TB language generally in imperative sentences as a command.

2) The Imperative Sentence as a Request 
(1) DTB: Pinggirhon jo parbasuon i!

TB : Hambiranghon jolo cuci tangan i!

In sentence number (1), the structure can be analyzed as follows in DTB language "Pinggirhon jo parbasuon i!".

The imperative sentences as a request can be showed with word "pinggirhont" as a request, "jo" is the particle, "parbasuon" is the object, " $i$ " is adverb of direction. But in TB language generally, 'pinggirhon' is 'hambiranghon'. In DTB use 'jo' after 'pinggirhon', but in TB use 'jolo' after 'hambiranghon'.

(2) DTB :Lean jo panggu on tu ibana!

TB : Lehon hamu ma jolo panggu on tu ibana

In sentence number (2), the structure can be analyzed as follows in DTB language "Lean jo panggu on tu ibana."

The imperative sentences as a request can be showed with word "Lean" as a request, "jo" is the particle, "on" is the adverb; "panggu to ibana" is the object. But in TB language generally, word 'lean' is written 'lehon' as a request, 'hamu' is the subject, ' $m a$ ' is the particle, 'jolo' is the particle, 'panggu' is the object, 'on' is the adverb, 'tu ibana' is the object.

(3) DTB: Sip jo!

TB : Sip jolo.

In sentence number (3), the structure can be analyzed as follows in DTB language, "Sip jo." The imperative sentences as a request can be show with word "Sip" as a request; " jo" is the particle. But in TB language generally, "Sip jolo." The imperative sentences as a request can be show with word "Sip" as a request; "jolo" is the particle. There is no difference between DBL and TBL in the structure sentence. The difference is showed for word ' $j o$ ' and 'jolo' as the particle.

(4) DTB: Sori jo, di jabu ma hamu.

TB : Santabi di jabu jolo hamu ate

In sentence number (4), the structure can be analyzed as follows in DTB language, "Sori jo, di jabu ma hamu." The imperative sentences as a request can be showed with word "Sori" as a request, "jo" is the particle, "di" is the particle, "jabu" is the object, "ma" is the particle, and "hamu" is the object. But in TB language generally, 'Santabi di jabu jolo hamu ate'.

The imperative sentences as a request can be showed with word "Santabi" as a request, "di" is the particle, "jabu" is the object, "jolo" is the particle, and "hamu" is the object.

\section{3) The Imperative Sentence as a Prohibition}

(1) DTB :Tongka mandokhon goarni natua tua.

TB: Tongka do dohonon goarni natua- tua.

In sentence number (1), the structure can be analyzed as follows in DTB language, "Tongka mandokhon goarni natua-tua". The imperative sentences as a prohibition can be show with word "Tongka" as a prohibition, while "mandokhon" is the adverb, "goarni" is the object, "natua-tua" is the object. But in TB language generally, 'Tongka do dohonon goarni natua-tua'. 
The imperative sentences as a prohibition can be show with word "Tongka" as a prohibition, "do' as a particle, while "dohonon" is the adverb, "goarni" is the object, "natua-tua" is the object.

The difference between DTB language and TB language generally in the sentences is for word 'mandokhon' in DTB and for word 'dohonon' in TB language generally. 'Mandokhon' and 'dohonon' has same meaning is say.

(2) DTB: Unang adong na meret sian on

TB : Unang adong na morot sian on.

In sentence number (2), the structure can be analyzed as follows in DTB language and TB language generally, "Unang adong na meret sian on".

The imperative sentences as a prohibition can be show with word "Unang" as a prohibition, while "adong na" is the particle, "meret" is the verb, "sian" is the particle, and "on" is the adverb. There is no difference between DTB and TB language generally in the sentences.

(3) DTB:Unang dipamago tintin $i$

TB: So tung dmiagohon ho tintin $i$

In sentence number (3), the structure can be analyzed as follows in DTB language, "Unang dipamago tintin $i$ ". The imperative sentences as a prohibition can be showed with word "Unang" as a prohibition, while "pamago" is the verb, "tintin" is the object, and " $i$ " is the adverb or direction. But in TB language, "So tung dimagohon ho tintin $i$

The imperative sentences as a prohibition can be showed with word "So tung" as a prohibition, while "dimagohon" is the verb, ' $h o$ ' is the object, "tintin" is the object, and " $i$ " is the adverb or direction.

(4) DTB: Unang ho jonok tu asar ni ulok $i$

TB : So tung jonok ma ho tu asar ni ulok $i$

In sentence number (4), the structure can be analyzed as follows in DTB language, "Unang ho jonok tu asar ni ulok i". The imperative sentences as a prohibition can be showed with word "Unang" as a prohibition, while " $h o$ " is the object, "jonok" is the adverb, "to" is the particle, "asar" is the object, "ni ulok" is the object, and "i" is the adverb. But in TB language generally, 'So tung jonok ma ho tu asar ni ulok i'.

The imperative sentences as a prohibition can be showed with word "So tung" as a prohibition, "jonok" is the adverb, " $m a$ " is the particle, while " $h o$ " is the object, "tu' is the particle, "asar" is the object, "ni ulok" is the object, and "i" is the adverb.

\section{CONCLUSION}

The result of this research can be conluded:

1. The differences between Doloksanggul Toba

Batak language and Batak Toba language generally are:

a. The structure of imperative sentence.

We can see from the pattern:

(1) Positive Imperative Sentence Form:

Doloksanggul Batak Toba (DBT)

(a) Verb+Particle+ Subject + Object Compliment

(b) Verb + Object + Particle 
(c) Verb+Particle + Object + Article

Batak Toba (BT) generally:

(a) Verb + Subject + Object Compliment

(b) Object + Article + Verb

(c) Verb + Particle +Object + Article

(2) Negative Imperative Sentence Form:

DTB:

(a) Auxiliary Verb + Verb + Object + Article

(b) Auxiliary Verb + Subject +Verb + Object Compliment + Article

TB generally:

(a) Auxiliary Verb + Verb + Object + Article

(b) Auxiliary Verb + Particle + Verb + Object Compliment

(c) Auxiliary Verb + Verb + Particle + Subject +Object Compliment + Article

b. Using particle ' $m a$ ' and ' $d o$ ' there is use in Toba Batak language general in the sentences. But in Doloksanggul Toba Batak language, for using particle 'do' is never used.

c. Based on using intonation between Doloksanggul Toba Batak language is harder than Toba Batak language generally.

2. The similarity between Doloksanggul Toba

Batak language and Toba Batak language generally are:

a. In basic structure in sentence, they are positive and negative imperative.

b. The using particle ' $m a$ '

c. The using negative auxiliary verb 'tongka. 


\section{REFERENCES}

Aikhenvald, Alexandra Y. 2014. “Commands: a cross-linguistics view”. Language and Culture Research Centre, James Cook University. Retrived on February 20, 2016 from https://research.jcu.edu.au/lcrc/steroom/commands.../position-paper.

Amelia, Kiki R. 2012. “Kesantunan Imperatif Bahasa Jepang Dalam Drama Tada Kimi Wo Aishiteru”. Chi'e: Journal of Japanese Learning and Teaching. Chi'e 1 (1) 2012. Retrieved on May 2nd, 2016 from http://journal.unnes.ac.id/sju/index.php/chie.

Beauman, S. 1988. Destiny. Toronto:Bantam Books.

Finch, Geoffrey. 2005. Key concept in Language and Linguistics. New York: Palgrave Macmillan.

Isaraj, Merita. 2010. A Comparative Study of Imperative Sentences In English And Albanian Language. Journal Practice And Theory In Systems of Education, Volume 5 Number 3, 2010.

Karepouwan, Vita. 2013. "Kalimat Imperatif dalam Novel The Kill Order Karya James Dashner”. Jurnal Elektronik Fakultas Sastra Sam Ratulangi. Vol. 1, No. 1. Retrived on April 21th, 2016 from www.ejournal.unsrat.ac.id.

Kridalaksana, Harimurti. 2008. Kamus Linguistik. Jakarta: PT Gramedia Pustaka Utama.

Loss, Eugene, et. al. 2004. Sentence. Glosarry of Linguistics Term. Retrived on January, 10th, 2016 from www.sil.org/linguistics/Glosarry Of Linguistics Term/What Is A Sentence. htm.

Postdam, Eric. 2003. "Syntactic Issues in the English Imperative". Journal Glot International Vol. 7, No. 1/2 January/February 2003 (1-7). Retrived on April 22th, 2016 from www.clas.ufl.edu/users/postdam/papers/glod.pdf.

Radford, Andrew, et. al. 2009. Linguistics: An Introduction. Cambridge: Cambridge University Press.

Rahardi, Kunjana R. 1999. "Imperatif dalam Bahasa Indonesia: Penanda-penanda Kesantunan Linguistiknya”. Jurnal Humaniora Volume XI, No. 2. Retrieved on May 1st, 2016 from www.jurnal-humaniora.fib.ugm.ac.id.

Sibarani, Robert. 1997. Sintaksis Bahasa Batak Toba. Medan: USU Press. 